\title{
Light and electron microscopy of Myxobolus sciades n. sp. (Myxozoa), a parasite of the gills of the Brazilian fish Sciades herzbergii (Block, 1794) (Teleostei: Ariidae)
}

\author{
Carlos Azevedo ${ }^{1,2 /+}$, Graça Casal ${ }^{1,3}$, Ivete Mendonça ${ }^{4}$, Erisson Carvalho ${ }^{4}$, Patrícia Matos ${ }^{5}$, Edilson Matos ${ }^{6}$ \\ 1Departamento de Biologia Celular, Instituto de Ciências Biomédicas Abel Salazar, Centro Interdisciplinar de Investigação Marinha e Ambiental, \\ Universidade do Porto, Largo Prof. Abel Salazar 2, 4099-003 Porto, Portugal ${ }^{2}$ King Saud University, Riyadh, Saudi Arábia ${ }^{3}$ Departamento de Ciên- \\ cias, Instituto Superior de Ciências da Saúde Norte, Cooperativa de Ensino Superior, Politécnico e Universitário, Gandra, Portugal ${ }^{4}$ Departamento \\ de Veterinária, Laboratório de Sanidade Animal, Universidade Federal do Piauí, Teresina, Pl, Brasil '5aboratório de Animais Aquáticos, Universi- \\ dade Federal do Pará, Belém, PA, Brasil ' Laboratório de Pesquisa Carlos Azevedo, Universidade Federal Rural da Amazônia, Belém, PA, Brasil
}

A myxosporean parasite in the gill lamellae of the freshwater teleost fish, Sciades herzbergii (Ariidae) (Block, 1794), from the Poti River (Northeast of Brazil) was described by light and electron microscopy studies. Polysporic histozoic cyst-like plasmodia containing several life-cycle stages, including mature spores, were observed. The spores were pyriform and uninucleate, measuring $9.15 \pm 0.39 \mu \mathrm{m}(n=50)$ long, $4.36 \pm 0.23 \mu \mathrm{m}(n=25)$ wide and $2.61 \pm 0.31 \mu \mathrm{m}(n=25)$ thick. Elongated pyriform polar capsules $(P C)$ were of equal size $(4.44 \pm 0.41 \mu \mathrm{m}$ long and $1.41 \pm 0.42 \mu \mathrm{m}$ in diameter) and each contained a polar filament with 9-10 coils obliquely arranged in relation to the axis of PC. The PC wall was composed of two layers of different electron densities. Histological analysis revealed the close contact of the cyst-like plasmodia with the basal portion of the epithelial gill layer, which exhibited some alterations in the capillary vessels. Based on the morphological and ultrastructural differences, the similarity of the spore features to those of the genus Myxobolus and the specificity of this host to previously described species, we describe a new species named Myxobolus sciades $n$. sp. in this study.

Key words: ultrastructure - parasite - Myxosporea - Myxobolus sciades n. sp. - gill - Brazilian fish

The genus Myxobolus (Bütschli, 1882) (family Myxobolidae) is one of the largest myxosporean groups and its members are important pathogens of freshwater and marine fish in several geographical areas (Eiras et al. 2005b, Lom \& Dyková 2006). In a recent synopsis, 744 Myxobolus species have been identified parasitizing fish (Eiras et al. 2005b) and more recently, 792 named species of the same genus, including seven infecting amphibians, have been described (Lom \& Dyková 2006). However, this number has been successively increasing over the years by the continuing description of new species in different countries, including Brazil (Casal et al. 2006, Martins \& Onaka 2006, Eiras et al. 2007, Adriano et al. 2009a, b, Azevedo et al. 2009).

Most of the Brazilian Myxobolus species have been described based on only light microscopy descriptions and diagrammatic drawings (Walliker 1969, Kent \& Hoffman 1984, Molnár \& Békési 1993, Gioia \& Cordeiro 1996, Molnár et al. 1998, Adriano et al. 2002, Cellere et al. 2002, Eiras et al. 2005a, 2007, Martins \& Onaka 2006); even fewer have been described using light and ultrastructural observations (Casal et al. 1996, 2002, 2006, Azevedo et al. 2002, 2009, Tajdari et al. 2005, Adriano

Financial support: Eng. António de Almeida Foundation (Porto, Portugal), CNPq, CAPES

+ Corresponding author: azevedoc@icbas.up.pt

Received 22 October 2009

Accepted 27 January 2010 et al. 2009a) as well as molecular analyses (Adriano et al. 2009b). However, some specific aspects of the histopathology have been simultaneously reported by invasion of different organs; Myxobolus spp most frequently infects the gills of fish (Molnár \& Békési 1993, Molnár 2002, Eiras et al. 2005a, Casal et al. 2006, Lom \& Dyková 2006, Adriano et al. 2009a, Azevedo et al. 2009).

In this paper, we describe light and ultrastructural data for a new myxosporidian species found in the gill of the teleost fish, Sciades herzbergii, which was collected from a river Northeast of Brazil.

\section{MATERIALS AND METHODS}

A parasite found in the secondary gill lamellae of the freshwater teleost fish, S. herzbergii (Block, 1794) (family Ariidae) (Brazilian common name mandi), was studied. Ten specimens were collected from June-August of 2009 in the Poti River $\left(05^{\circ} 05^{\prime} \mathrm{S} 42^{\circ} 48^{\prime} \mathrm{W}\right)$ near the city of Teresina [state of Piauí (PI)] northeast of Brazil. The fish were lightly anaesthetised with MS 222 (Sandoz Laboratories) and dissected. Cyst-like plasmodia with numerous mature spores located in the basal insertions of the gill lamellae were examined and measured in fresh mounts with a light microscope equipped with Nomarski differential interference contrast (DIC) optics. For transmission electron microscopy (TEM), small, parasitised fragments of the infected gills were fixed in $3 \%$ glutaraldehyde in $0.2 \mathrm{M}$ sodium cacodylate buffer $(\mathrm{pH}=7.2)$ at $4^{\circ} \mathrm{C}$ for $10 \mathrm{~h}$, washed overnight at $4^{\circ} \mathrm{C}$ with the same buffer and post-fixed in $2 \% \mathrm{OsO}_{4}$ buffered with the same solution for $3 \mathrm{~h}$ at $4^{\circ} \mathrm{C}$. The fragments were 

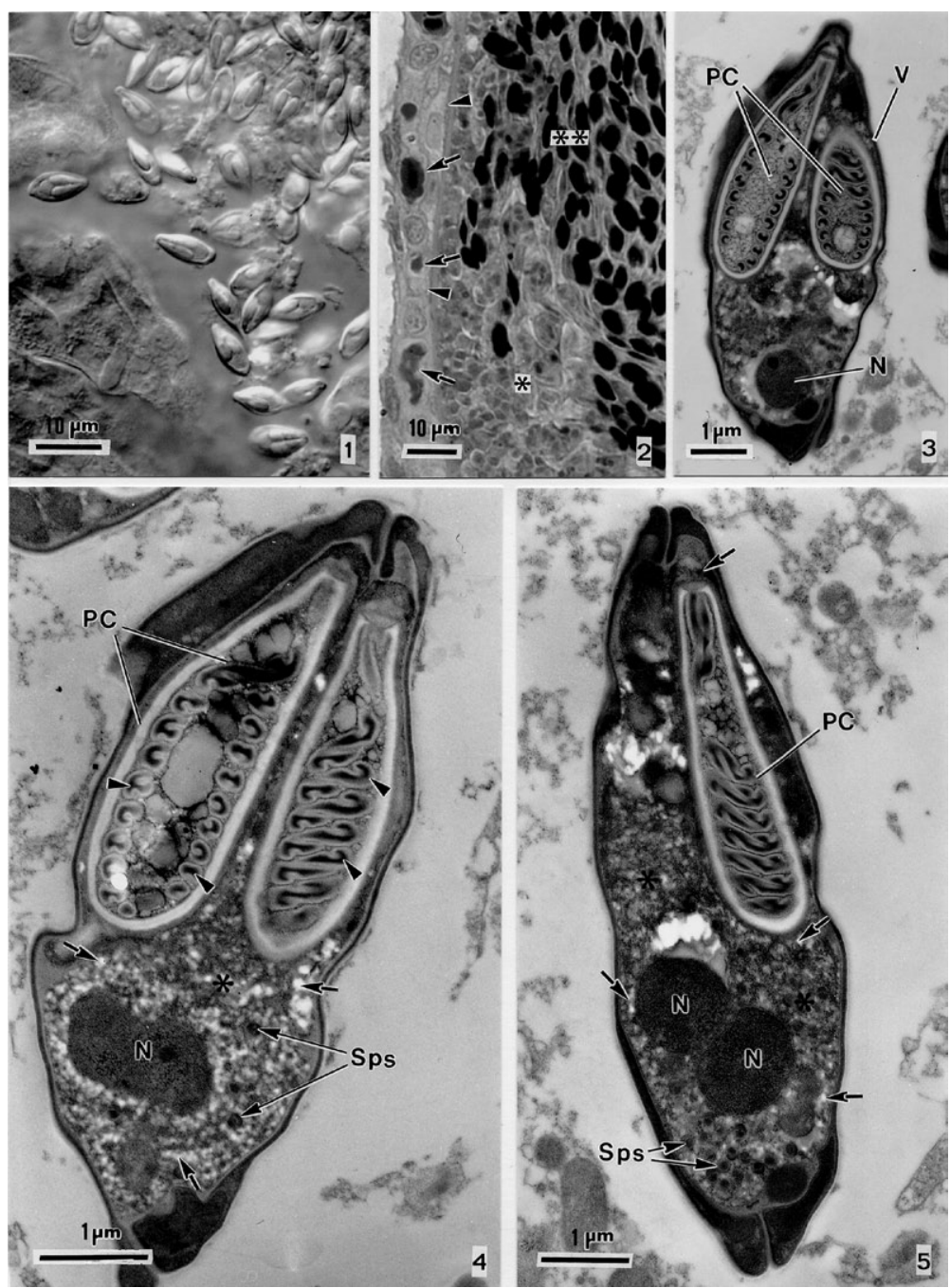

Figs 1-5: Myxobolus sciades n. sp. parasite of the freshwater Brazilian fish Sciades herzbergii. 1: free fresh spores released from cyst-like plasmodia observed in differential interference contrast; 2: semi-thin section showing the periphery of cyst-like plasmodia in close contact with the epithelial gill cells (arrowheads) in which some aspects of compressed capillaries (arrows) were observed. Internally some developmental stages, immature spores $(*)$ and mature spores $(* *)$, sectioned at different levels are randomly distributed throughout the cyst-like plasmodium; 3: spore sectioned longitudinally showing the valves (V), the two polar capsules (PC) and one of the two nuclei (N); 4: ultrastructural details of a spore sectioned longitudinally showing the organization of the PC and the arrangements of the polar filaments (arrowheads). The sporoplasm (*) shows the $\mathrm{N}$ surrounded by an extensive system of rough endoplasmic reticulum containing several vesicles and cisternae (arrows) and some sporoplasmosomes (Sps); 5: longitudinal section (lateral view) showing PCs and sporoplasm with the two Ns and some Sps both surrounded by the endoplasmic reticulum containing several vesicles and cisternae (arrows).

dehydrated in an ascending ethanol series with propylene oxide and embedded in Epon. Blocs were cut and semi-thin sections were stained with methylene blue and photographed under a light microscope (DIC). Ultrathin sections were double stained with aqueous uranyl acetate and lead citrate and then observed under a JEOL $100 \mathrm{CXII}$ TEM operated at $60 \mathrm{kV}$.

\section{RESULTS}

We observed several cyst-like plasmodia, with diameters up to $60 \mu \mathrm{m}$, localised in the bases of the gill lamellae, which contained numerous spores. In total, $60 \%$ of the specimens (6 out 10) were parasitised and based on the spore morphology, parasites were identified as a myxosporidian belonging to the genus Myxozoa (Bütschli, 1882) (Figs 1,2). The infected gill had cellular and nuclear hypertrophy that was accompanied by morphological changes, such as organelle disorganisation and cytoplasm vacuolisation (Fig. 2).

We propose the establishment of a new species based on the morphology and ultrastructure results obtained for host specificity and the comparison with spores from previously described species.

Following Lom and Dyková (2006), this new species is classified as follows: Phylum Myxozoa (Grassé, 1970); Class Myxosporea (Bütschli, 1881); Order Bivalvulida (Schulman, 1959); Family Myxobolidae (Thélohan, 1892); Genus Myxobolus (Bütschli, 1882). 

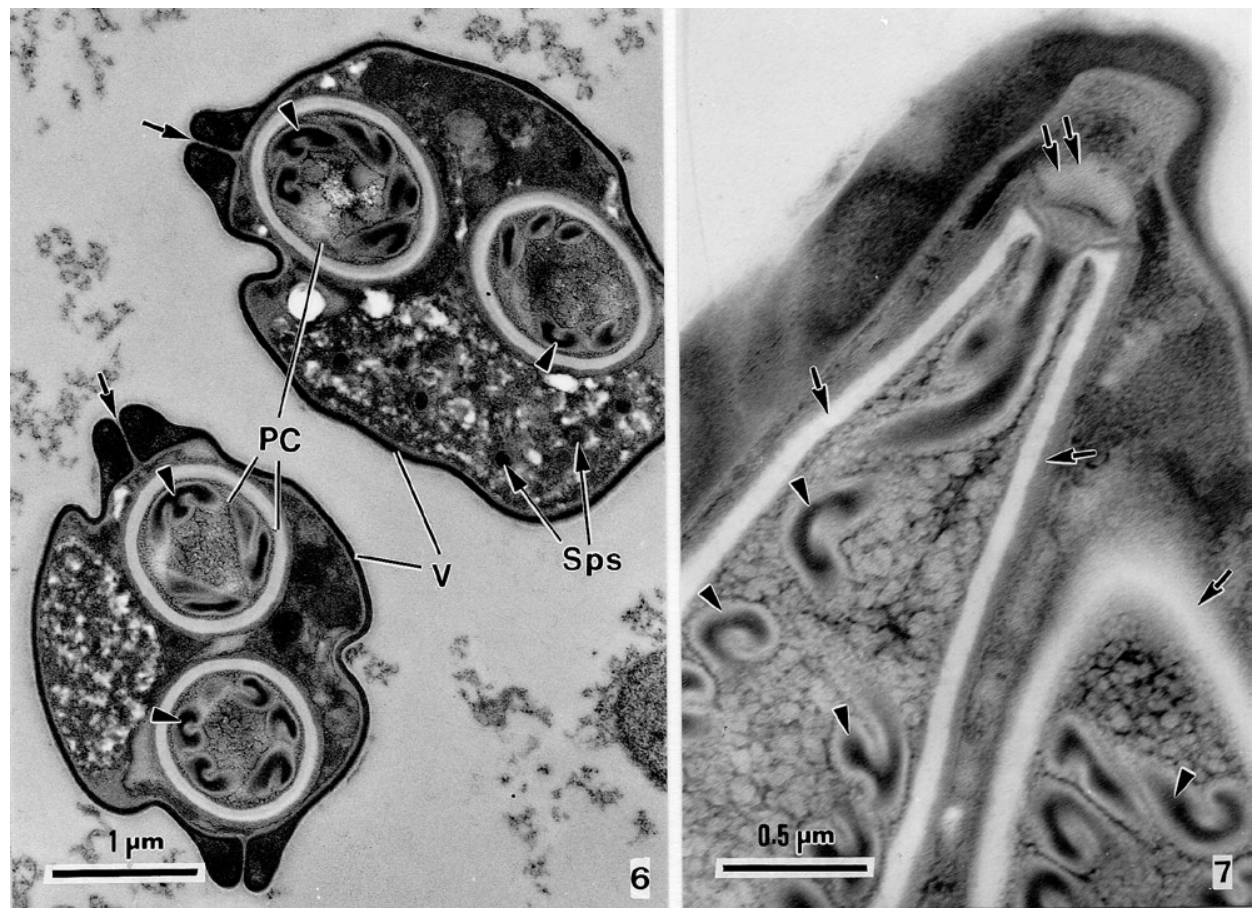

Figs 6, 7: Myxobolus sciades n. sp. parasite of the freshwater Brazilian fish Sciades herzbergii. 6: two spores sectioned transversally showing the valves (V) and there suture lines (arrows), polar capsules (PC), different sections of the polar filaments (arrowheads) and some sporoplasmosomes (Sps); 7: detail of the apical region of the PCs showing the PC wall (arrows) composed of two layers and the apical stopper (double arrows) and the different sections of the polar filament (arrowheads).

Myxobolus sciades n. sp.

(Figs 1-8)

Description - vegetative stages - White, ellipsoidal to spherical-shaped polysporic histozoic cyst-like plasmodia measuring up to $60 \mu \mathrm{m}$ in diameter were present in different life cycles stages, including numerous matures spores (Figs 1,2), in the secondary gill lamellae of the fish, $S$. herzbergii. The fresh mature spores had a pyriform shape, tapering anteriorly to a slight knob-like end and they measured $9.15 \pm 0.39 \mu \mathrm{m}(\mathrm{n}=50)$ long, $4.36 \pm$ $0.23 \mu \mathrm{m}(\mathrm{n}=25)$ wide and $2.61 \pm 0.31 \mu \mathrm{m}(\mathrm{n}=25)$ thick (Figs 1,2$)$. The spore wall was thin ( $62 \mathrm{~nm}$ thick) and smooth, comprising two equally-sized valves joined by a sutural ridge that is slightly oblique in relation to the spore axis (Figs 3-5). No mucus envelope was observed at the surface of the spore. Internally, two polar capsules (PCs) with an elongated pyriform shape and equal size, $4.44 \pm 0.61(\mathrm{n}=15) \mu \mathrm{m}$ in length and $1.41 \pm 0.42 \mu \mathrm{m}(\mathrm{n}$ $=15$ ) in diameter, were located side by side at the same level, each containing a polar filament with 9-10 coils (PFCs) (Figs 3-7). The PCs occupied approximately twothirds of the total spore length (Figs 3, 4). The apical portion of the PCs contained a developed stopper in close contact with the valves (Figs 4, 5, 7, 8). At the posterior pole of the spore, a sporoplasm contained two spherical nuclei with uniform chromatin (each $\sim 1.5 \mu \mathrm{m}$ in diameter), some sporoplasmosomes, glycogen granules and an extensive system of rough endoplasmic reticulum with vesicles and cisternae (Figs 4, 5).
Type host - Teleost fish S. herzbergii (Block, 1794) (family Ariidae) (14-22 cm in length, on average).

Site of infection - Cyst-like plasmodia containing spores were located in the bases of the secondary gill lamellae.

Prevalence of infection - Six out of 10 (2/4 males and $4 / 6$ females) adult fish (60\%) were parasitised.

Type locality - Poti River $\left(05^{\circ} 05^{\prime} \mathrm{S} 42^{\circ} 48^{\prime} \mathrm{W}\right)$, near the city of Teresina (PI), Brazil.

Type data and depository - A glass slide containing semi-thin sections of mature spores and some other developmental stages of the hapantotype was deposited in the International Protozoan Type Slides Collection at the Smithsonian Institution, Washington DC 20560, USA under acquisition USNM \# 1134556.

Etymology - The specific epithet name (sciades) derives from the generic name of the host species.

Histopathology - Histopathological alterations in the surrounding region where the cyst-like plasmodia were located showed deformities of the gill lamellae and compression of the capillaries.

\section{DISCUSSION}

The spores obtained from the gill lamellae of the fish, S. herzbergii, revealed morphological and ultrastructural characteristics similar to those previously described for the genus Myxobolus (Bütschli, 1882) (Lom \& Dyková $1992,2006)$. In the present paper, we describe a new his- 


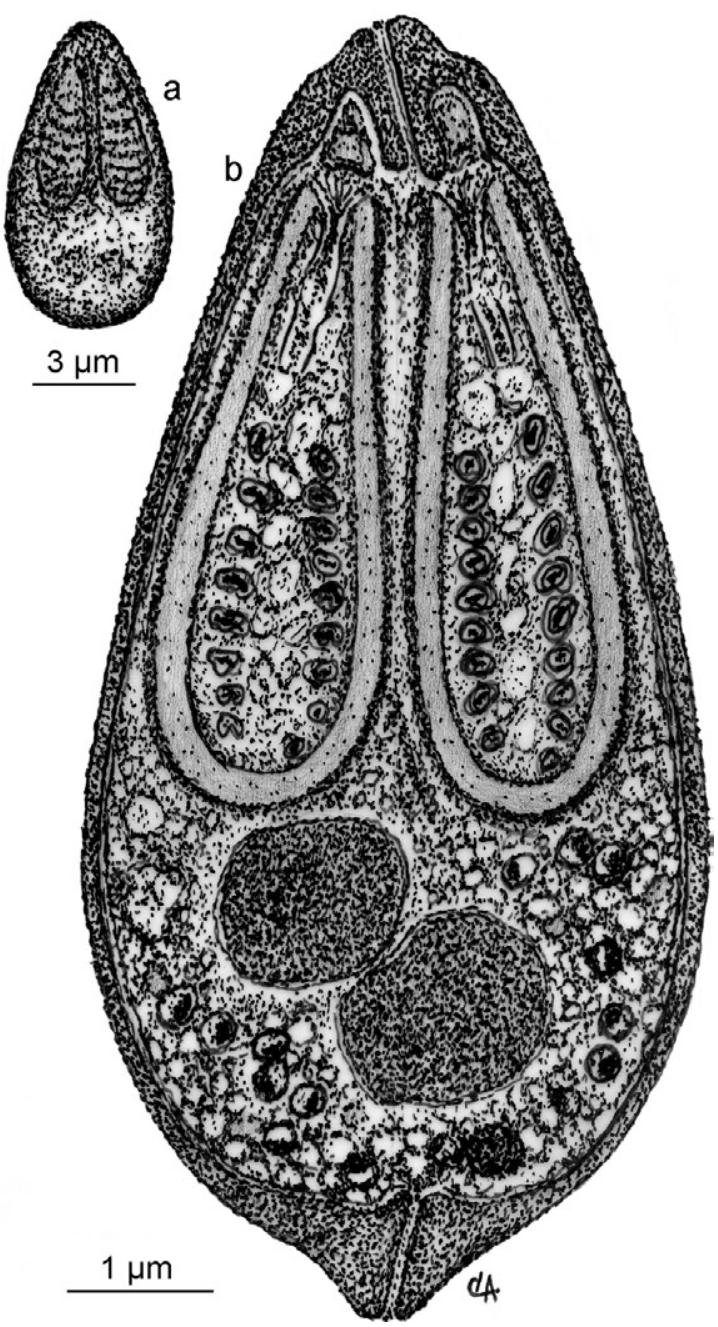

Fig. 8: Myxobolus sciades n. sp. parasite of the freshwater Brazilian fish Sciades herzbergii. Schematic drawings of a valvar view of the spore morphology, as observed in differential interference contrast (a) and in longitudinal ultra-thin section in transmission electron microscopy (b). tozoic species found in the gill lamellae, which is frequently the preferential site for the development of fish myxosporeans (Molnár 2002). Unfortunately, studies of several Myxobolus species reported to infect the same organ make few references to the ultrastructural morphology of the spores and the plasmodia (Lom \& Dyková 1992). Additionally, most of the early species descriptions are vague, with few light micrographs and line drawings of the spores. Until now, only 27 Myxobolus species have been reported from South America, of which 24 valid species were described in Brazilian fish. When comparing the present results with those for the different Myxobolus spp previously described in Brazilian fish (Table), we observed several morphological differences in the dimensions and shape of the spores and PCs as well as the number, position and organisation of the coils in the PFCs. Species such as Myxobolus inaequus (Kent \& Hoffman 1984), Myxobolus desaequalis (Azevedo et al. 2002) and Myxobolus absonus (Cellere et al. 2002) were excluded from the possibility of belonging to the same species, because these organisms posses two unequallysized PCs. Reported species infecting organs other than the gills were also excluded from the comparative table.

Of the 24 species present in Brazilian fish, only nine can be carriers of Myxobolus spp because this species has equal-sized PCs and infects freshwater fish gills (Table). The spores of $M$. sciades $n$. sp. described herein are smaller (in length, width and thickness) than the species referred to in Table (except the Myxobolus condrophilus spores, which are much smaller). Furthermore, the number of PFCs described has 9-10 coils, whereas all PFCs described in the different species have fewer coils (except for Myxobolus braziliensis, which has a similar number). However, M. braziliensis has a different ultrastructural organisation of the PFCs, which is evident in the apical region of the PCs, compared to M. sciades n. sp., which contains a complex apical stopper that is in close contact with the spore wall.

TABLE

Comparative measurements (in $\mu \mathrm{m}$ ) of the spores with equal-sized polar capsules from Myxobolus spp parasitizing gills of the Brazilian freshwater fish

\begin{tabular}{lcccccccc}
\hline Myxobolus spp & Sp L & Sp W & Sp T & PC L & PC W & PF C & Ct / Pm & References \\
\hline Myxobolus condrophilus & 6 & 4.5 & 3.5 & 3 & - & - & - & Nemeczek (1926) \\
Myxobolus noguchii & 13.6 & 8.5 & - & 6.8 & 2.2 & - & - & Pinto (1928) \\
Myxobolus colossomatis & 11.8 & 6.9 & - & 6.0 & 2.1 & $7-8$ & - & Molnár and Békési (1993) \\
Myxobolus braziliensis & 10.2 & 5.2 & 3.7 & 5.3 & 1.4 & $9-11$ & 300 & Casal et al. (1996) \\
Myxobolus insignis & 14.5 & 11.3 & 7.8 & 7.6 & 4.2 & 6 & $20-80$ & Eiras et al. (2005a) \\
Myxobolus peculiaris & 25.2 & 15.4 & - & 10.7 & 4.4 & $4-5$ & - & Martins and Onaka (2006) \\
Myxobolus cordeiroi & $\sim 11$ & $\sim 7.3$ & - & $\sim 5.4$ & $\sim 1.5$ & $5-6$ & $\sim 2000$ & Adriano et al. (2009a) \\
Myxobolus salminus & 10.1 & 6.1 & 5.0 & 4.6 & 1.7 & $7-8$ & $\sim 100$ & Adriano et al. (2009b) \\
Myxobolus heckelli & 12.7 & 6.6 & 4.0 & 2.9 & 1.7 & $4-5$ & $\sim 250$ & Azevedo et al. (2009) \\
Myxobolus sciades n. sp. & 9.15 & 4.36 & 2.61 & 4.44 & 1.63 & $9-10$ & 60 & Present study \\
\hline
\end{tabular}

Ct/Pm: cysts/plasmodia; PC L: polar capsule length; PC W: polar capsules width; PF C: polar filament coils; Sp L: spore length; Sp T: spore thick; Sp W: spore width. 
Comparison of our results with other Myxobolus species that infect the gills of Brazilian freshwater fish (Table) revealed significant differences in morphometric characters (size and body shape) of the spores, ultrastructural organisation of the PCs and their PFCs and host specificity. However, when comparing other international Myxobolus species that infect the gill tissues of freshwater fish (Eiras et al. 2005b) to those described herein, we observed that spores with a similar shape and size have several morphological differences in both length and width of PC as well as their position in relation to the $\mathrm{PC}$ axis. This analysis suggests that the presently described parasite is different from other Myxobolus spp and therefore, M. sciades is a new species.

The pathology associated with gill infection by $M$. sciades $\mathrm{n}$. $\mathrm{sp}$. was similar to that observed in other Brazilian Myxobolus spp described previously (Molnár et al. 1998, Tajdari et al. 2005, Adriano et al. 2009a, b, Azevedo et al. 2009). The compression of the surrounding capillaries seems to indicate that this parasite has pathogenic activity.

\section{ACKNOWLEDGMENTS}

To the iconographic work of J Carvalheiro and to the anonymous reviewers, for their most helpful comments and suggestions.

\section{REFERENCES}

Adriano EA, Arana S, Alves AL, Silva MRM, Ceccarelli PS, Henrique-Silva F, Maia AAM 2009a. Myxobolus cordeiroi n. sp., a parasite of Zungaro jahu (Siluriformes: Pimelodiade) from Brazilian Pantanal: morphology, phylogeny and histopathology. Vet Parasitol 162: 221-229.

Adriano EA, Arana S, Carriero MM, Naldoni J, Ceccarelli PS, Maia AAM 2009b. Light, electron microscopy and histopathology of Myxobolus salminus n. sp., a parasite of Salminus brasiliensis from the Brazilian Pantanal. Vet Parasitol 165: 25-29.

Adriano EA, Arana S, Ceccarelli PS, Cordeiro NS 2002. Light and scanning microscopy of Myxobolus porofilus sp. n. (Myxosporea: Myxobolidae) infecting the visceral cavity of Prochilodus lineatus (Pisces: Characiformes: Prochilodontidae) cultivated in Brazil. Folia Parasitol 49: 259-262.

Azevedo C, Casal G, Matos P, Ferreira I, Matos E 2009. Light and electron microscopy of the spore of Myxobolus heckelii n. sp. (Myxozoa), parasite from the Brazilian fish Centromochlus heckelii (Teleostei: Auchenipteridae). J Eukaryot Microbiol 56: 589-593.

Azevedo C, Corral L, Matos E 2002. Myxobolus desaequalis n. sp. (Myxozoa: Myxosporea), parasite of the Amazonian freswater fish, Apteronotus albifrons (Teleostei: Apteronotidae). J Eukaryot Microbiol 49: 485-488.

Casal G, Matos E, Azevedo C 1996. Ultrastructural data on the life cycle stages of Myxobolus braziliensis n. sp. parasite of an Amazonian fish. Europ J Protistol 32: 123-127.

Casal G, Matos E, Azevedo C 2002. Ultrastructural data on the spore of Myxobolus maculatus n. sp. (phylum Myxozoa), parasite from the Amazonian fish Metynnis maculatus (Teleostei). Dis Aquat Org 51: 107-112.
Casal G, Matos E, Azevedo C 2006. A new myxozoan parasite from the Amazonian fish Metynnis argenteus (Teleostei: Characidae): light and electron microscope observations. J Parasitol 92: 817-821.

Cellere EF, Cordeiro NS, Adriano EA 2002. Myxobolus absonus sp. n. (Myxozoa: Myxosporea) parasitizing Pimelodus maculatus (Siluriformes: Pimelodidae), a South American freshwater fish. Mem Inst Oswaldo Cruz 97: 79-80.

Eiras JC, Abreu PC, Robaldo R, Pereira-Junior J 2007. Myxobolus platanus n. sp. (Myxosporea: Myxobolidae), a parasite of Mugil platanus Günther, 1880 (Osteichthyes: Mugilidae) from Lagoa dos Patos, RS, Brazil. Arq Bras Med Vet Zootec 59: 895-898.

Eiras JC, Malta JCO, Varella AMB, Pavanelli GC 2005a. Myxobolus insignis sp. n. (Myxozoa, Myxosporea, Myxobolidae), a parasite of the Amazonian teleost fish Semaprochilodus insignis (Osteichthyes: Prochilodontidae). Mem Inst Oswaldo Cruz 100: 245-247.

Eiras JC, Molnár K, Lu YS 2005b. Synopsis of the species of Myxobolus Bütschli, 1882 (Myxozoa: Myxosporea: Myxobolidae). Syst Parasitol 61: 1-46.

Gioia I, Cordeiro NS 1996. Brazilian myxosporidians' check-list (Myxozoa). Acta Protozool 35: 137-149.

Kent ML, Hoffman GL 1984. Two new species of Myxozoa, Myxobolus inaequus sp. $\mathrm{n}$. and Henneguya theca sp. n. from the brain of a South American knife fish, Eigemannia virescens (V.). J Protozool 31: 91-94.

Lom J, Dyková I 1992. Myxosporidia (Phylum Myxozoa). 7. Protozoan parasites of fishes. Developments in aquaculture and fisheries science. Dev Aquat Fish Sci 26: 159-235.

Lom J, Dyková I 2006. Myxozoa genera: definition and notes on taxonomy, life-cycle terminology and pathogenic species. Folia Parasitol 53: 1-36.

Martins ML, Onaka EM 2006. Henneguya garavelli n. sp. and Myxobolus peculiaris n. sp. (Myxozoa: Myxobolidae) in the gills of Cyphocharax nagelli (Osteichthyes: Curimatidae) from Rio do Peixe Reservoir, São José do Rio Pardo, São Paulo, Brazil. Vet Parasitol 137: 253-261.

Molnár K 2002. Site preference of fish myxosporeans in the gill. Dis Aquat Org 48: 197-207.

Molnár K, Békési L 1993. Description of a new Myxobolus species, M. colossomatis $\mathrm{n}$. sp. from the teleost Colossoma macropomum of the Amazon River basin. J Appl Ichthyol 9: 57-63.

Molnár K, Ranzani-Paiva MJ, Eiras JC, Rodrigues EL 1998. Myxobolus macroplasmodialis $\mathrm{n}$. $\mathrm{sp}$. (Myxozoa: Myxosporea), a parasite of the abdominal cavity of the characid teleost, Salminus maxillosus in Brazil. Acta Protozool 37: 241-245.

Nemeczek A 1926. Beiträge zur Kenntnis der Myxosporidienfauna Brasiliens. Arch Protistenk 22: 143-149.

Pinto C 1928. Myxobolus noguchii, M. stokesi e Henneguya iheringi, espécies novas de myxosporideos de peixes de água doce do Brasil. Bol Biol 12: 41-43.

Tajdari J, Matos E, Mendonça I, Azevedo C 2005. Ultrastructural morphology of Myxobolus testicularis n. sp., parasite of the testis of Hemiodopsis microlepis (Teleostei: Hemiodontidae) from the NE of Brazil. Acta Protozool 44: 377-384.

Walliker D 1969. Myxosporidea of some Brazilian freshwater fishes. J Parasitol 55: 942-948. 